\title{
correspondence
}

\section{GMAG: NIH guidelines are not the way}

SiR,-Professor Alan Williamson is well within his rights to complain (1 February, page 346 ) that there was "no real debate" about the proposed basis of GMAG's new way of working at the public meeting on 21 December, although it is by no means clear at whom the complaint should be directed. By inference, GMAG is somehow to blame. Professor Williamson could just as well have blamed those among his colleagues who chose to use up what time there was in echoing (and amplifying) what the platform had already acknowledged - that there must be special arrangements for some (but not all) homogenic experiments. He might also blame himself for not having brought up the issues to which he now draws attention.

Of these, perhaps the most important is Professor Williamson's assertion that the UK could with advantage adopt the NIH guidelines and be done with further introspection. It is therefore worth saying that the NIH guidelines are in several respects defective, at least if one supposes that some of the conjectured hazards of genetic manipulation may (or might be) real. First, their classification of animal virus experiments is irrational, and takes no account of conjectured immunological hazards in particular. Second, the potential importance of expression compared with mere replication has been entirely overlooked in the "broadly based public debate" that Professor Williamson admires. Third, even the new NIH guidelines are not constructed in such a way that what must be presumed to be a growing class of experiments without risk can be progressively identified and excluded from rigorous restraint.

I am one of those who believe that if GMAG does not change its procedures soon, we shall find that events force on us a decision between the NIH guidelines and doing the research elsewhere. It is of course ironical that we should be faced with such a choice when the hazards of genetic manipulation remain conjectural. In my opinion, however, it is disingenuous of Professor Williamson and other would-be genetic manipulators to complain at the constraints which they invited a mere four years ago. Making a bonfire of the regulations now will cause only trouble. Surely it is in the interests of the scientific community that they should be dismantled by rational means.

GMAG's proposed way of working offers precisely such a possibility, provided that genetic manipulators will play their part in gathering the necessary data. My own belief is that if the proposed system were adopted and willingly accepted, we should find that before the end of 1980 all but a handful of experiments were no more restricted than by the requirements of "good microbiological practice". Is not that a chance worth taking?

Yours faithfully, JOHN MADDOX

Nuffield Foundation, London, UK

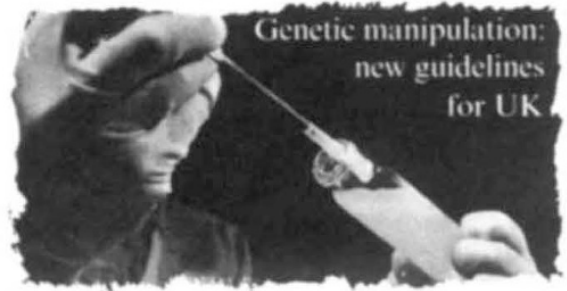

from Nature, 9 November

Risks of recombinant DNA

\section{regulations}

SIR,-A more appropriate title for your editorial (November 9, page 103) would have been 'The absence of reason continues' or 'Reason ought to prevail', rather than 'Now reason can prevail'. Let me explain why I consider the regulations of the recombinant DNA technique and the new GMAG proposal as unreasonable.

- Since the risks of the recombinant DNA technique are principally in the realm of hypothetical scenarios and science fiction, it is totally unreasonable to propose any complex regulations.

- GMAG is proposing to estimate the imaginary risks of various types of experiments, but totally ignores the true risks of regulations themselves. As I have discussed before (Trends in Biochemical Sciences 3, NZ43; 1978), the regulations lead to many real dangers to science and society while their benefits are restricted to supporting the livelihood of the

bureaucrats who administer the regulatory machinery. It is totally unreasonable to institute regulations without first evaluating the benefit-to-risk ratio of the proposed regulations themselves, and this ratio in the case of recombinat DNA regulations approaches zero.

As wisely argued by J. D. Watson (The New Republic 180,12;1979) it is folly to control any human endeavour which may benefit society, just because it is impossible to provide a perfect proof that no risks exist or can be imagined. There is a high probability that such bureaucratic controls will be detrimental to the best interests or society, rather than having any benefits.

The GMAG proposals on the complex numerical estimations of the purely imaginary risks bear a resemblance to the Hans Christian Andersen fable on the 'Emperor's New Clothes' and appear to be a rather pathetic example of where the recombinant DNA folly could lead us. Let's hope that at the end reason will prevail and all regulations will be converted to a one-sentence statement proposed bv D. Stetten, the first chairman of the NIH Recombinant DNA Advisory Committee: "The conditions of containment appropriate for any recombinant DNA experiment are those which are dictated bv the most virulent or dangerous organism entering into that experiment" Yours faithfullv. W. Szybalski

Mc Ardle Laboratory for Cancer Research.

University of Wisconsin, USA

\section{Wisdom in universities}

SIR,-Your leader 'Converting intelligence into wisdom' (25 January, page 251 ) draws undeniably sound conclusions about our lamentable shortage of far-sighted generalists. But in my view you err in claiming that education must be 'immensely wasteful' to be effective. It is simply not true that most of what we learn at school or college helps illuminate future thinking in an indefinable way. Quite the converse: the insistence on specialist teaching, parrot-fashion learning and the unremitting adherence to cumbersome orthodoxies in the academic world are the antithesis of what education ought to mean, and drives out of the minds of all but the most stalwart student any aspiration to true independence or heterodox creativity.

Teaching was originally the responsibility of elders who were accepted as sources of wisdom. It is now a source of profitable employment for those who, all too often, lack the wisdom to do anything better. University teachers are rarely taught to teach. University students who do well in their examinations of ten look back to realise that they did so in spite of how they were taught, rather than because of it; and few people will argue with the claim that most of what they were taught was distinguished by its irrelevance to conditions in the real world. I have recently been looking into some of the attempts made by universities to get together with industry, for example, in an attempt to make available the wisdom that we like to imagine lurks in the academic fold. In many instances the level of common literacv (to cite just that) is as low in the university-sponsored material as it is in the most backward corner of narrow-minded industry. The inefficiency of universities with regard to staff appointment procedures, administration and communication is remarkable - but is entirely in accord with what I have come to expect.

This is not to say that all university departments are incompetently run. But the very fact that any are, undermines what faith society ought to have in the seats of learning. Until there is a thorough reappraisal of what education should mean there is little chance of injecting excitement and liveliness into the academic world. There will be few generalists as long as there is no market for them; and until the unthinkable occurs, and the reappraisal you call for in your leader begins, the opportunities for real progress and revolutionary new insights into man's predicament will remain unwanted. unfashionable, and frankly embarrassing.

It is, I fear, impossible to upset an annle-cart that is so large, and so weighed down with passengers who are enioying the apples. It's fun trying, though.

Yours faithfully, BRIAN J. FORD

Science Unit, Cardiff, UK. 